\title{
The Differential Impact of the Experiential- Entrepreneurial Learning Method on the Entrepreneurial Intentions of Higher Education Students
}

\author{
Yasin Mohammed Ali \\ Bahir Dar University, College of Education and Behavioral Science, \\ Department of Psychology, Ethiopia \\ https://orcid.org/0000-0003-2879-9988 \\ Reda Darge Negasi \\ Bahir Dar University, College of Education and Behavioral Science, \\ Department of Psychology, Ethiopia \\ https://orcid.org/0000-0002-3789-578X
}

\begin{abstract}
This study has comparatively examined the differential impact of the experiential-entrepreneurial learning method on the entrepreneurial intentions of students against the traditional entrepreneurial-teaching method of the course in Entrepreneurship and Small Business Management in Wollo University, Ethiopia. The research design appropriated was a quasi-experimental non-equivalent comparison-group design. The data for the study were drawn from 202 prospective graduating students. An entrepreneurial-intentional questionnaire (EIQ) was used to collect the data. To test the impact of course intervention, ANCOVA and SEM_path analysis were employed. As the findings indicated, a significant mean difference in the entrepreneurial intention and its antecedents were obtained between the experiential-entrepreneurial method and the traditional entrepreneurialteaching method group of the study participants. The relationships of variables included in the theory of planned behavior (TPB) have been affected by the two teaching-learning methods univocally. The findings have practical implications and recommendations for the teachinglearning processes of entrepreneurship in higher education.
\end{abstract}

Keywords: entrepreneurial intention; entrepreneurial learning; Experiential learning; higher education

\section{Introduction}

Ethiopia has recorded a rapid expansion in the development of higher education: a $10.2 \%$ of the enrolment rate in $2015 / 17$, and a high graduation rate 
for the past 15 years (FDRE MoE, 2018). To realize the Government's plan of transitioning the country into a middle-income category by 2025 , the gross enrolment rate needs to be at least $22 \%$. However, the higher education participation rate remains low. Issues associated with relevance, quality, and equity have compounded the problem (MoE, 2018; Molla, 2018). The political crisis that Ethiopia has encountered for the past five years, i.e., 2017-2021, also complicated and negatively affected its fast-growing economy, stability, as well as the mission accomplishment of higher education. Hence, from employment to poverty-reduction and innovation, Ethiopian higher education learners are faced with personal, institutional, and systematic challenges.

Contrary to the Higher Education Proclamation 650/2009 statements on learning and its practices, thiopian higher education institutions are still highly behaviorist (lectures, homework, quizzes, and the like) that focus on knowledge acquisition, which is known to intensify the level of lecturers' involvement and control, learner passivity and indecisiveness (Tadesse et al., 2018; Zerihun et al., 2012) and also with a surface-learning outcome. Therefore, it is necessary to question the realisation of the Government's call for a "student-centred" learning method.

Having in mind the limitations of the framework of the assessment which they have applied, Hubb et al. (2015) investigated the practices of entrepreneurial education in Ethiopian universities. Their findings showed that the practice was in poor shape; that is, it lacked policy direction, being incongruent with the growth and development plan of the country. It further lacked basic curriculum and pedagogical appropriateness and was found to be methodologically unstructured. Likewise, Gerba (2012) indicated that entrepreneurial education in public universities was only introductory, methodologically weak, and unstructured in its objective. This study aims to understand the extent to which (a) those issues affect the entrepreneurial-intentional development of learners in Ethiopian higher education; and (b) the alternative experiential-entrepreneurial learning method, which addresses the problem under the following research questions:

I. Do experiential and traditional entrepreneurial teaching and learning methods affect the entrepreneurial intention of students differently?

II. How do the experiential and traditional learning methods of an entrepreneurship course affect the association of entrepreneurial intention and its antecedents?

\section{The Theoretical and Empirical Frameworks}

\subsection{Experiential-Entrepreneurial Learning}

Experiential learning provides an understanding of human learning and education as a lifelong process that depends on the knowledge pursuit of social psychology, philosophy, and cognitive psychology (Kolb, 1984). Therefore, as Kolb maintained, experiential learning is a "philosophical rationale for the primary role of personal experience in experiential learning" (Kolb, 1984, p. 18). In experiential learning, the interplay of the cognitive-learning process and affect- (emotion) related experiences determine the outcome of the learning 
content, which is being covered. Humans are not inherently empty barrels, who passively wait for agencies to fill them up (Kolb, 2014).

In a humanistic psychological tradition, human experience and its interpretations are uniquely valued. Therefore, experiential learning particularly recognises and values feeling, as part and parcel of the learning process and its cognitions. Experiential learning, according to Lewis and Williams (1994; p.5), refers to "learning from experience or learning by doing". Similarly, others have also defined it as learning from experience (Usher \& Soloman, 1999). All these definitions involve experience, action, and the active participation of the learner.

It is either entrepreneurial learning or any other field of study, theories of learning in psychology and education that have an eclectic, multi-disciplinary, and dynamic method on how to deal with the learning itself, the learners, as well as the learning environment. By supporting this, Béchard and Grégoire (2005) maintained that the association between the learning paradigms in educational psychology and entrepreneurial learning are close. Accordingly, when designing such teaching-learning methods for such courses, awakening to and abiding by the process to the principles of learning science in psychology are reported as being reasonable (e.g., Biggs, 2012).

Experiential entrepreneurial learning involves innovative learning methods, which are highly dependent on the constructivist approach, including experiential learning; problem-solving, and project-based learning (Hägg \& Gabrielsson, 2019). Jones and Iredale (2010) also suggested that for the sake of engaging (far from mere reading or listening to a teacher) and enhancing the motivation of learners, entrepreneurship in education requires experiential learning style strategies, which are predominantly problem solving and learning through practice or by actually doing.

As Leal-Rodríguez and Albort-Morant (2019) indicated, experiential learning in an entrepreneurial education helps learners to have an opportunity to bring their diverse life experiences into the learning scene, and to interact in a meaningful way in which equality, freedom, and other views are adequately acknowledged. In entrepreneurial learning, where experiential learning is the framework of the process, mistakes in learning are cultural (Chapman et al., 2016), and where roleplay activities, and case presentations are rich sources of learning (Park \& Choi, 2014).

Entrepreneurial behaviors, or competencies, are the results of learners' engagement with or immersion in entrepreneurial activity processes, which can grant learners an experience of how being an entrepreneur is a matter of growth (Lackéus et al., 2016). Although the context is different from that of entrepreneurship as Tadesse et al. (2020) reported, the informal cooperative learning method, which is a type of the active and experiential learning method, was significantly associated with teaching effectiveness and greater learning satisfaction among bachelor degree students, rather than with their counterparts. 
Therefore, experiential learning can be considered as a participatory form of learning that gives learners opportunity for testing their cognitive processes to analyze and synthesize information in an active and immersive learning context (Feinstein et al., 2002).

\subsection{Entrepreneurial Intentions}

Based on Ajzen's (1991) theory of planned bbehavior (TPB), intention is the predictor of any behavior. On the other hand, intention is also predicted by the underlying belief of the individual, which comprises attitude, normative beliefs, and control beliefs. Accordingly, TPB is modelled by several studies to investigate the ipact of EE on EI and entrepreneurial-related behaviors (Liñan \& Chen, 2009; Mwasalwiba, 2010). Intention is an indicator of the extent to which individuals are motivated to perform certain actions, and the energy they are willing to expend, in order to achieve that intended behavior (Lorti \& Castogiovanni, 2015). Others have also confirmed the explanatory power of intention to motivate action, either for entrepreneurial behavior, or other behaviors (Schlaegel \& Koenig, 2014; Laguía et al., 2019).

The existing research in the area of entrepreneurship and intentional development to venture on creation shows that entrepreneurship courses have a positive impact on learners' attitude towards self-employment (Liñán \& Chen, 2009; Souitaris et al., 2007; Mueller, 2011; Schlaegel \& Koenig 2014). The other two predictors of entrepreneurial intention (EI), which are entrepreneurial subjective normative beliefs (ESNB) and entrepreneurial perceived behavioral control (EPBC), are also reported; and they can be influenced by proper entrepreneurial learning-intervention strategies.

As TPB posited, subjective normative belief is the perceived social pressure of significant others to perform, or not, on some behavioral intentions (Solesvik et al., 2013). These influences of parents, teachers, and friends can be against, or for an individual's value system, norms, and beliefs. Through such dynamic processes, the entrepreneurial intention of an individual can be derived and shaped (Ajzen, 2001). SNBs are determined by the perceived expectations of people in the referent group formed by a given person, and the strength of that individual's motivation to comply with that expectation (Fishbein \& Ajzen, 2011). Therefore, SNB can be appropriated in two ways; either by the perception or expectations of the referent people, or by the level of compliancemotivation of the individual (Panwar, 2020).

According to TPB, EPBC refers to the perceived capability of mastering the tasks required for venture creation by planned intent. This perceived capability or belief of an individual on how to perform an entrepreneurial action is dependent on the knowledge and skills of entrepreneurial activities and processes (Chen et al., 1998). In terms of the impact of EE on PBC, Sánchez (2013) reported that the perceived performance of students helped with how to accomplish entrepreneurial actions, while simultaneously competencies can be enhanced by entrepreneurial education. Other researchers in the area also reported that the 
relationship between PBC and EI is positive (Fayolle \& Gailly, 2015; Karimi et al., 2016).

As far as the exploration of this study is concerned, research reports on the impact of teaching or learning methods of PBC are scant. Consequently, the differential impact of the EELM over the TETM will be tested by EPBC.

From the 1990s, research on the impact of EE on entrepreneurial intentions and its antecedents has accumulated. Most of these studies employed the intentional models of TPB (Ajzen, 2017). The model predicts action from its intentions. As Schlaegel and Koenig (2013) described, although the two models have made recommendations on what sort of actions are needed for effective intention, a large number of research works have exclusively focused on predicting and explaining intentions. This approach lacks a complete picture of the nexus between intention and action (Van Gelderen et al., 2008). However, business ventures are only established if, and only if, the intention is followed by an action. This gap has been recently identified; efforts are required to confirm the empirical investigations of the link between entrepreneurial intentions and subsequent actions (Reuel Johnmark et al. 2016; Van Gelderen et al., 2015). According to reports of these studies, large numbers of respondents who expressed their intention to engage in a business-creation process do not appear to have produced any concrete actions (Van Gelderen et al., 2008).

Accordingly, these days, in an intention, or particularly in EI literature, the intention-action gap, that is, the intention implementation or the implementation- intentional issue is becoming a popular, and an important issue in a research field. This research has tested the association among intentions, the antecedents, and the implementation-cue activities initiated by learners.

According to Gollwitzer and Sheeran (2006, p.82), implementational intentions are "if-then plans that connect good opportunities to act with cognitive or behavioral responses that are effective in accomplishing one's goals. It bridges the intention to the behavioral gap." Accordingly, they clarify or specify the behavior that individuals will execute for attaining their goal of intention, and the situation in which they pass through. Research in implementation intention is still in its infancy. Particularly in entrepreneurial intentions, the findings are scant. Therefore, followed by the previous discussions on the consecutive discussions of literature, the impact of entrepreneurship education, particularly a compulsory course provided to higher education prospective graduate students has been tested on their entrepreneurial intentions and related personal agencies.

Answering such questions would help by narrowing gaps on how to deal with the relationship of intention and subsequent actions through designing theorydriven, flexible, free-sized, and adaptable entrepreneurial learning methods in higher education. 


\section{The Methods}

\subsection{Research Design and Course-Intervention Description}

In this study, non-equivalent groups, and a pretest-posttest quasi-experimental design was applied. Although the uncontrollability of the data from various groups is mentioned as a limitation of the design (Lackeus et al., 2015), it has several advantages. By creating the temporal precedence of the independent variable to the dependent variable (Cook \& Campbell, 1979) and consequently establishing a cause-effect relationship, the design was identified. The learning progress and any changes of the study participants were compared with the learning outcomes of the course Entrepreneurship and Small Business Management which comprised four months in duration, $48 \mathrm{CrHr}$ contacts, and delivered by a semester-based linear format. Both study groups had no previous experience of entrepreneurial education or short-term training in entrepreneurship. Hence, concerning the assignment, the only supposed difference was solely the teaching-learning method employed.

The experimental group of study participants was exposed to an entrepreneurial course that was enriched by the experiential learning method, whereas the control group of students learned the course in entrepreneurship by the existing traditional entrepreneurial teaching method. The main focus of this study, i.e., entrepreneurial learning methods applied for the experiential learning group of study participants, is described as follows.

In the experiential group, the learning methods that are underpinned in learning by employing the principle were largely practised. Among others, a field-based feasibility study (aimed to enhance the skill of students' market analysis, opportunity identification, information seeking, planning, and riskidentification), business plan writing (a prerequisite for a student's loan service request, and which served as a reference document in the profitability of the business-creation exercise of students) was also used as part of the entrepreneurial learning method. The other core learning method was the business-creation exercise (BCE). It was aimed at developing entrepreneurial behaviors among learners through contextualising and reinforcing personal entrepreneurial behaviors.

In this package of action-oriented learning, opportunity identification, businessplan presentation, student-loan access request, and payback were properly executed. Finally, the experiential entrepreneurial learning method was also enriched by utilising experiential learning methods. These teaching-learning activities were supported by the narrative of the entrepreneurs, the experience sharing of guest entrepreneurs, business company visits, and the service descriptions of financial institutions.

The control group students studied the entrepreneurship course by the conventional traditional teaching method. This method is accredited and approved by the Ministry of Science and Higher Education (MoSHE). Although lecturing was the main teaching method, business-plan writing and unstructured business-creation exercises have been regarded as the main 
practical teaching methods of the traditional entrepreneurial teaching method group of study participants.

\subsection{Participants and Study Groups}

This study was conducted at the Wollo University, Ethiopia. Both the experimental and the control groups of the participants were prospective graduating students drawn from the College of Agriculture. The demographic characteristics of the participants and their band of assignment for higher education, the credit hour allotted for the course Entrepreneurship and Small Business Management in each department were found to be evenly distributed. Therefore, it was logically justifiable to compare the experimental and the control group students' entrepreneurial intentions and the related entrepreneurial mind set changes through their respective entrepreneurial learning and teaching methods of the same course.

Accordingly, 202 participants were recruited from the four departments of the College of Agriculture, Wollo University. Accordingly, 88 students from the Control Group (in Plant and Animal Science departments), hereafter called the Traditional Entrepreneurial Teaching Method, or TETM and 114, under the Experimental Group (WSRM and RDAE departments), hereafter called the Experiential Entrepreneurial Learning Method or EELM students, participated in the study.

\subsection{Data Collection Instruments}

Based on Ajzen's (1991) theory of planned behavior (TPB) framework, Linan and Chen (2009) have developed a standardized measuring instrument of entrepreneurial intention (EIQ). Recently conducted research that used EIQ reported an appropriate psychometric quality and its acceptability (Da Costa \& Mares, 2016). Regarding the psychometric quality of EIQ, Linan and Chen (2009) reported that the reliability (Cronbach $\alpha$ ) of entrepreneurial-intention (EI), perceived behavioral control (PBC), subjective-normative belief (SNB), and entrepreneurial attitude (EAT) are $0.943,0.885,0.773$, and 0.897 respectively. Concerning the validity thereof, construct, discriminant and convergent validities have been reported, with a recommended range of acceptance.

While measuring entrepreneurial intention and its antecedents, EIQ has a different approach from that of the TPB's recommendation; considering beliefs (Fayolle et al., 2006). An aggregate of scale items that were Likert-type responses ranged from 1 (total disagreement) to 7 (total agreement) of each measured variable was employed. Thus, according to Linan and Chen (2009), in EIQ aggregate attitude, perceived behavioral control and subjective normative belief can be taken as a significant predictor of intention, while beliefs were not considered. Consequently, this research has adopted the EIQ of Linan and Chen (2009).

By using similar formats, in EIQ, the entrepreneurial intention was measured by six items (e.g., I am ready to do anything to be an entrepreneur). These are general sentences indicating the different aspects of intention. Chen et al. (1998) 
also used the same way of measuring entrepreneurial intentions. Entrepreneurial attitude also has been measured by general statements, e.g., a career as an entrepreneur is attractive for me, was chosen. In the same vein, while measuring SNB, EIQ has used one simpler scale in the validation process that includes three groups of reference people (e.g., If you decided to create a firm, would people in your close environment approve of that decision, i.e., family, friends and significant others?). Perceived behavioral control (PBC), which is, according to Ajzen (2001), broader than the concept of self-efficacy, was measured by self-efficacy items (Chen et al., 1998).

Consequently, aggregate measures were also employed for measuring SNB and PBC. In measuring EPBC, the EIQ included a six-item scale, five of which measure general self-efficacy, whereas the one item is a controllability statement.

In measuring entrepreneurial intention, implementation cues (EIIC) such as a self-developed questionnaire were employed. If students have a strong and genuine intention of becoming an entrepreneur, then they should show some active cues of entrepreneurial behavioral changes during the class, or after the class. These expected cues of entrepreneurial-behavioral changes are businessrelated actions, for instance, business plan preparation, saving, market research, business networking, or potential business-partner identification. Accordingly, six items were developed and the EIIC was measured. The process of item development of EIIC was guided by Gollwitzer (1999) and Gollwitzer and Sheeran (2006).

Finally, before the actual administration of the data-collection instrument, the psychometric qualities of all the antecedents of entrepreneurial intentions modelled by TPB and the immediate outcome of EI, i.e., EIIC, were tested by using a pilot study. Accordingly, the reliability indicator statistics of EI, EAT, ESNB, EPBC, and EIIC, were 0.94, 0.80, 0.93, 0.86, and 0.90 respectively. They were used for the actual data-collection of the study.

\subsection{Data Collection and the Organizational Communication Processes}

For this study, the actual data collection was conducted in two phases: the precourse intervention test and post-course intervention. The first phase (i.e., the pre-course intervention and the data for the test data collection) was conducted in February 2019 (i.e., the beginning of the second semester of the university's academic year schedule). The second phase (i.e., the post-course intervention and the test data collection) took place on June 15, 2019 (end of the academic year of the university schedule). During the first phase of the data collection, institutional rapport formation and securing work permits were properly entertained. Based on the application of the researcher, the management of Wollo University has indicated its willingness to cooperate with the intervention of the learning method, student loan access, and the BCE week organization. For the sake of the effectiveness of the intervention, a formal agreement between the university and the researcher was signed. 
Before the actual administration of the pretest, the participants of the study were provided with all the necessary information. Following the description of the purpose of the research and its processes, the questionnaire was dispatched (under the guidance and support of course teachers), based on the identification number of the study participants. Accordingly, the pretest data collection was administered in February 2019. Following a similar procedure as that of the pretest data collection, the post-test intervention data collection was conducted on June 15, 2019. Since each group of the study had information about the purpose of the study, with some reminders and cautions, the course teachers of each study group have managed all the processes of the post-course intervention of the data-gathering administration.

\subsection{Analysis Procedures}

The data analysis technique employed for testing the mean difference in the impact of the two methods was ANCOVA. On the other hand, the relationships of the antecedents of entrepreneurial intention and its implementation cue were determined by the SEM of path analysis. To test the inter-relationships among independent and dependent variables, by using the statistical analysis package AMOS 18.0 (analysis of moment structures), the SEM pass analysis was employed.

\section{The Results}

\subsection{Mean Differences of Entrepreneurship Course Methods on EI and Its Antecedents}

The $\mathrm{M}$ and SD of the measured variables for both the EELM and the TETM are indicated in Table 1. Accordingly, EAT $(\mathrm{M}=4.43, \mathrm{SD}=1.3), \mathrm{ESNB}(\mathrm{M}=3.4$, $\mathrm{SD}=1.6), \mathrm{EPBC}(\mathrm{M}=3.89, \mathrm{SD}=1.14)$, EI $(\mathrm{M}=3.7, \mathrm{SD}=1.2)$, and $\mathrm{EIIC}(\mathrm{M}=2.4 ; \mathrm{SD}=1.2)$ for the TETM group of study participants were recorded. On the other hand, EAT $(\mathrm{M}=5.7, \mathrm{SD}=0.94), \mathrm{ESNB}(\mathrm{M}=3.8, \mathrm{SD}=1.9), \mathrm{EPBC}(\mathrm{M}=5.4, \mathrm{SD}=0.96), \mathrm{EI}$ $(\mathrm{M}=5.6 ; \mathrm{SD}=1.1)$, and EIIC $(\mathrm{M}=4.9, \mathrm{SD}=1.1)$ were obtained for the participants of EELM. The mean scores of all the measured variables were higher for the study participants, who had learned entrepreneurship by the experiential entrepreneurial learning method.

Table 1: Mean and Standard Deviation of EI and Its Antecedents by Study Groups

\begin{tabular}{ccccc}
\hline Variables & Group & M & SD & N \\
\hline Eat & TETM & 4.43 & 1.32 & 88 \\
\multirow{2}{*}{ SNB } & EELM & 5.72 & 0.94 & 114 \\
& TETM & 3.39 & 1.58 & 88 \\
PBC & EELM & 3.81 & 1.91 & 114 \\
& TETM & 3.89 & 1.14 & 88 \\
EI & EELM & 5.45 & 0.96 & 114 \\
\multirow{2}{*}{ EIIC } & TETM & 3.7 & 1.2 & 88 \\
& EELM & 5.6 & 1.1 & 114 \\
& TETM & 2.4 & 1.2 & 88 \\
& EELM & 4.9 & 1.1 & 114 \\
\hline
\end{tabular}

Following the mean score presentation, through controlling all pretests, the significance of the mean differences of the various study groups was tested by 
ANCOVA. As the test results presented in Table 2 indicate, a significant mean difference in EAT and EPBC between the EELM and the TETM groups was obtained: $\mathrm{EAT}, F(1,197)=66.02 ; \mathrm{P}<0.00 ; \eta^{2}=0.255 ; \mathrm{PBC}, F(1,97)=106.22$; $\mathrm{P}<0.00 ; \mathrm{\eta}^{2}=0.35 ; \mathrm{EI}, \mathrm{F}(1,198)=129.59 ; \mathrm{P}<0.00 ; \mathrm{\eta}^{2}=0.40 ;$ and $\mathrm{EIIC}, \mathrm{F}(1,198)=$ 290.44; $\mathrm{P}<0.00 ; \mathrm{\eta}^{2}=0.60$.

Consequently, compared to the traditional entrepreneurial teaching method, the experiential entrepreneurial learning method was found to be higher in enhancing the entrepreneurial intention, its antecedents, and its implementation cue activities of the study's participants.

Table 2: ANCOVA Test of EELM and TETM Groups and Their Antecedents

\begin{tabular}{cccccccc}
\hline Dependent Variable & $\begin{array}{c}\text { Sum of } \\
\text { Squares }\end{array}$ & Df & $\begin{array}{c}\text { Mean } \\
\text { Square }\end{array}$ & F & Sig. & $\mathbf{\eta}^{2}$ \\
\hline Eat & Contrast & 84.69 & 1 & 84.69 & 66.02 & 0.00 & 0.25 \\
& Error & 252.73 & 197 & 1.28 & & & \\
SNB & Contrast & 7.82 & 1 & 7.82 & 2.53 & 0.11 & 0.013 \\
& Error & 609.58 & 197 & 3.09 & & & \\
PBC & Contrast & 114.28 & 1 & 114.28 & 106.22 & 0.00 & 0.35 \\
& Error & 211.94 & 197 & 1.08 & & & \\
& & & & & & & \\
EI & Contrast & 177.26 & 1 & 177.26 & 129.59 & 0.00 & 0.40 \\
& Error & 270.83 & 198 & 1.37 & & & \\
EIIC & Contrast & 317.71 & 1 & 317.71 & 290.44 & 0.00 & 0.60 \\
& Error & 216.59 & 198 & 1.09 & & & \\
\hline
\end{tabular}

On the other hand, although the mean score of the subjective normative beliefs of the study participants learned by the EELM were higher $(M=3.8, S D=1.9 \mathrm{Vs}$. $M=3.5, S D=1.3)$, the difference was statistically non-significant; $F(1,197)=2.53$; $P>0.11 ; \eta^{2}=0.013$.

\subsection{The Relationships between EI and the Antecedents}

The TPB model was tested by using the SEM path analysis. Based on the information provided in Table 3, a significant correlation between EPBC and EAT for the EELM group $(\mathrm{r}=0.251, \mathrm{p}<0.00)$ and TETM group $(\mathrm{r}=0.37, \mathrm{p}<0.00)$ was obtained. On the other hand, a significant correlation between EAT and SNB $(r=0.34, p<0.00)$ and EPBC and SNB $(0.21, \mathrm{p}<0.00)$ for the TETM group of study participants was obtained.

Table 3: Correlations of EI Antecedents by Study Groups

\begin{tabular}{ccccccc}
\hline & \multicolumn{3}{c}{ EELM ( N=114) } & \multicolumn{3}{c}{ TETM (N=88) } \\
\hline Variables & Eat & Esnb & Epbc & Eat & Esnb & Epbc \\
Eat & 1 & & & 1 & & \\
Esnb & 0.15 & 1 & & $0.342^{* *}$ & 1 & \\
Epbc & $0.251^{* *}$ & 0.173 & 1 & $0.369^{* *}$ & $0.210^{*}$ & 1 \\
\hline
\end{tabular}

According to the results of the model for testing, configurable invariance revealed that the $\mathrm{X}^{2}$ was non-significant $(p>0.05)$. The rest of the model-fit indices also suggested good model fits: $\mathrm{GFI}=0.99$; $\mathrm{AGFI}=0.95 ; \mathrm{NFI}=0.97 ; \mathrm{CFI}=$ 
0.1; TLI= 0.96; RMSEA $=0.00$. From this information, an inference can be drawn that the hypothesized multi-group model of TPB was fitting for both the new and the existing entrepreneurial course group study participants. Having established the goodness-of-fit for the unconstrained model, the testing process was further utilised to test for the invariance of the structure across the two groups.

According to the comparisons of the models indicated by Table 4, the results showed that although the parameters of the model were constrained, the three models had no significant differences $X^{2}(5, N=202 ;=7.80 ; p>0.167 ;=13.77$; $\mathrm{p}>0.25)$.

Additionally, when the structural weights of the model were assumed to be correct, the structural covariance model was also not significantly different $X^{2}(6$, $\mathrm{N}=202 ;=5.97 ; \mathrm{p}>0.426$ ). This provided further evidence that the three models were homogeneous. Thus, the TPB model's understudy was invariant across the two groups.

Table 4: Comparing the Unconstrained and the Constrained Models

\begin{tabular}{cccccccc}
\hline Model & DF & CMIN & P & $\begin{array}{c}\text { NFI } \\
\text { Delta-1 }\end{array}$ & $\begin{array}{c}\text { IFI } \\
\text { Delta-2 }\end{array}$ & $\begin{array}{c}\text { RFI } \\
\text { rho-1 }\end{array}$ & $\begin{array}{c}\text { TLI } \\
\text { rho2 }\end{array}$ \\
\hline \multicolumn{8}{c}{ Assuming the model unconstrained to be correct } \\
Structural weights & 5 & 7.804 & 0.167 & 0.040 & 0.041 & 0.079 & 0.088 \\
Structural covariance & 11 & 13.775 & 0.246 & 0.070 & 0.072 & 0.081 & 0.090
\end{tabular}

Assuming model Structural weights to be correct

$\begin{array}{llllllll}\text { Structural covariance } & 6 & 5.971 & 0.426 & 0.031 & 0.032 & 0.002 & 0.002\end{array}$

According to the test of the regression reported in Table 5, EAT and EPBC were found to be significant predictors of EI for both the EELM and the TETM, $\beta=$ $0.38, p<0.00 ;=0.24, p<.00, \beta=0.39, p<00 ; 00=0.26, p<0.00$ respectively. However, SNB was found to be a significant predictor of EI for the TETM group of participants alone; $\beta=0.13, p<0.01$, and it was found to be non-significant for the EELM group of participants; $\beta=0.012, p>0.87$.

Table 5: Regression weights and level of significance of the EELM and TETM course model effects

\begin{tabular}{|c|c|c|c|c|c|c|c|c|c|c|}
\hline \multicolumn{6}{|c|}{ EELM Group $(\mathrm{N}=114)$} & \multicolumn{5}{|c|}{ TETM Group ( $\mathrm{N}=88)$} \\
\hline \multicolumn{2}{|c|}{ Estimate } & S.E. & C.R. & $P$ & $\mathbf{R}^{2}$ & Estimate & S.E. & C.R. & $P$ & $R^{2}$ \\
\hline Eat & 0.38 & 0.066 & 5.79 & $* * *$ & & 0.392 & 0.0800 & 4.8911 & $* * *$ & \\
\hline Esnb & 0.12 & 0.048 & 2.612 & 0.0022 & & 0.012 & 0.072 & 0.16 & 0.871 & \\
\hline Epbc & 0.24 & & 3.503 & $* * *$ & & 0.264 & 0.087 & 3.048 & 0.002 & \\
\hline EI & 0.422 & 0.091 & 4.640 & $* * *$ & & 0.245 & 0.086 & 2.857 & 0.004 & \\
\hline \multirow[t]{2}{*}{ Epbc } & 0.25 & 0.082 & 3.066 & 0.002 & & 0.109 & 0.082 & 1.329 & 0.184 & \\
\hline & & & & & $\begin{array}{l}0.402 \\
0.312\end{array}$ & & & & & $\begin{array}{l}0.389 \\
0.161\end{array}$ \\
\hline
\end{tabular}

The remaining two findings shown in Table 5 indicate that EI significantly predicted EIIC in the EELM group, $\beta=0.42, \mathrm{P}<0.00$, and in the TETM group, $\beta$ 
$=0.25, \mathrm{p}<0.004)$. However, EIIC was only significantly predicted from PBC in the EELM group, $\beta=0.25, \mathrm{p}<0.002$, and it was insignificant for the existing TETM group of participants, $\beta=0.11, \mathrm{p}<0.18$. In the same table, the predictors of EI and EIIC have explained $40.2 \%$ and $31.2 \%$, and $38.9 \%$ and $16.1 \%$ of the variation of each predicted variable in the experiential and traditional entrepreneurial teaching-learning method groups of the study participants respectively.

\section{Discussions}

\subsection{Differential Impacts of Experiential Entrepreneurial Learning Method on EI and its Antecedents}

To determine the effectiveness of the newly designed EELM, a comparative study with the existing traditional entrepreneurial teaching method was conducted. Accordingly, the EI, EAT, EPBC, and EIIC of students who learned the course entrepreneurship by the experiential entrepreneurial learning method were significantly improved more than the students who had learned the same entrepreneurship course by the existing traditional entrepreneurial teaching method. In this research, such prominent differential achievement of students can be attributed to the nature of the newly designed experiential entrepreneurial learning method.

In this regard, there are different arguments on how experiential learning meaningfully and desirably affects the mind, heart, and hands of learners when compared to the conventional traditional lecture-dominated teaching method of higher education.

While arguing against the effect of the lecture-based entrepreneurship course delivery and supporting the action-oriented entrepreneurial learning method, Higgins and Elliott (2011) suggested that the traditional classroom pedagogy is less effective in achieving actionable entrepreneurial learning outcomes. Similarly, Bae et al. (2014) and Nabi et al. (2017) also argued that the traditional pedagogy is questionable in enhancing entrepreneurial intention. Heinonen and Poikkijoki (2006) also reported that compared with the different types of experiential learning methods, the traditional lecture-driven entrepreneurial course delivery could inhibit the development of entrepreneurial skills in general, and critical thinking, in particular.

In addition to these reports, which are consistent with the present study's findings, many others also found that action-oriented entrepreneurial learning is effective for higher-order learning outcomes (Järvi, 2015). Mukesh et al. (2020) and Padilla-Angulo (2017) also reported a consistent finding with the present study in entrepreneurial intention and perceived behavioral control of learners. According to this research finding, among the study groups, those who have been exposed to action-learning pedagogy achieved a significantly higher level of entrepreneurial-perceived behavioral control and entrepreneurial intention, when compared to those taught by traditional classroom pedagogy.

On the other hand, although a significant improvement was observed in subjective normative belief for both methods, there was no significant difference 
between the new experiential and the existing entrepreneurial courses $F(1,197)$ $=2.23 ;$ P>0.12; Partial Eta Squared $=0.01$. In line with these findings, many researchers reported that a subjective normative belief has not been improved in entrepreneurial education. According to these groups of researchers, there was no significant direct relationship between EI and ESNB (Autio et al. 2001; Krueger et al., 2000).

However, negating the present findings and those of previously reported works, a positive impact of EE on students' subjective normative beliesf has been reported (Mueller, 2011). Consequently, such univocal findings should be confirmed by future research projects.

\subsection{Relationships between EI and its Antecedents}

The present study has confirmed that a significant correlation between entrepreneurial-perceived behavioral control and attitude for the experiential group $(\mathrm{r}=0.251, \mathrm{p}<0.00)$ and the traditional teaching method group $(\mathrm{r}=0.37$, $\mathrm{p}<0.00)$ has been obtained. However, the relationship between attitude and subjective normative beliefs $(\mathrm{r}=0.34, \mathrm{p}<0.00)$ and perceived behavioral control and subjective normative belief $(0.21, \mathrm{p}<0.00)$, was only found to be significant for the traditional teaching method group of students. Regardless of its statistical significance, SNB has also been found to have a positive relationship with attitude and PBC among the experiential groups of the participants. In this regard and in line with the present research findings, researchers (Autio et al., 2001; Krueger et al., 2000) reported that the relationships of SNB with intention, attitude, and PBC are weak. TPB also treated SNB as an important but weak contributor of intentions.

The SEM path analysis results showed that the intentional model (TPB) was valid for representing the entrepreneurial intentional development of students. Adequate model fit was obtained and the significant paths from the three antecedents to entrepreneurial intention were found. However, subjective normative beliefs had a positive non-significant impact on the entrepreneurial intentions of the existing course model $(\beta=0.097, p>0.054$, which was closer to $0.05)$ and the existing entrepreneurial course group of participants $(\beta=0.012$, $\mathrm{p}>0.87)$.

Regarding the relationship of SNB in the TPB model, consistent with the findings of the study, its impact on intention has been reported as weak. Owing to this research dispute, some researchers have omitted it from the model (Peterman \& Kennedy, 2003), while others have reported that its effect was nonsignificant (Krueger et al., 2000).

On the other hand, the newly added variable entrepreneurial intentional implementation cue that can be considered as a closer predictor of actual job creation behavior was significantly predicted from the entrepreneurial intention and perceived behavioral control of students taught by the experiential method. This finding was consistent with the theoretical direction (Gollwitzer, 1999) and empirical report of implementation intention planned critical cues of how 
intention could be realised by answering questions relating to when, where, and how students would carry out the intended action and the correspondence between the intended and the actual behavior (Oettingen \& Gollwitzer, 2013; Gollwitzer \& Sheeran, 2006).

Accordingly, although similar findings in the relationship of entrepreneurial intention and entrepreneurial intention implementation cue were reported, among students taught by the existing traditional teaching-oriented method, perceived behavioral control has not predicted the entrepreneurial intentional implementation cue $(\beta=0.11, p>0.184)$.

The predictors of entrepreneurial intention (attitude, SNB, and PBC) have explained $40.2 \%$ (the EELM) and 38.9\% (the TETM) of its variance. Accordingly, attitude, PBC and SNB have explained $28.5 \%, 8.1 \%$ and $3.6 \%$ (the EELM); and $32.2 \%$ and $6.6 \%$ (TETM) of the variance of entrepreneurial intention respectively. Among the antecedents, the larger share of explaining entrepreneurial intention was attributed to attitude. This has been supported by various previous research projects (Malabana \& Swanepoel, 2015).

However, when compared to those researchers, the present research could not replicate perceived behavioral control, which explains intention as being as large as attitude. The smaller contribution of PBC in explaining the variance of EI obtained in this research has also deviated from the research model of Ajzen's TPB. According to Ajzen (1991), perceived behavioral control explains 20-40\% variance of intention. SNB was found to be the lowest predictor and explainer of entrepreneurial intention. This finding also coincides with those of many researchers (e.g., Muller, 2011).

Concerning the amount of the share that the antecedents of EI have found, the present finding supported the empirical findings. Among others, most studies of entrepreneurial intention found a value of $\mathrm{R}^{2}$ between $20 \%$ and $40 \%$; for example, 55.5\% (Linan \& Chen, 2009), 35\% (Krueger et al., 2000), 45\% (Tkachev \& Kolvereid, 1999), 30.3\% (Autio et al., 2001), 32\% (Souitaris et al., 2007), and $38 \%$ (Van Gelderen et al., 2008).

It is noted that the contribution of the subjective norms in the TPB was generally found to be weak in previous research projects (Autio et al., 2001). As the contribution of individual predictors of entrepreneurial intention is depicted in the analytical section of this paper, the values of the path coefficients obtained are consistent with those of previous studies. For instance, the range of path coefficients of attitude was found to be between $0.215(\mathrm{p}<0.001)$ and 0.306 , subjective normative beliefs range between $0.028(p<0.05)$ to $0.356(p<0.001)$, and perceived behavioral control ranges from $0.16(\mathrm{p}<0.001)$ to 0.380 (Autio et al., 2001; Kolvereid, 1996; Souitaris et al., 2007; Tung, 2011) in entrepreneurial education.

On the other hand, entrepreneurial intention and perceived behavioral control have explained 33\% (the new course) and 16.1\% (of the existing course-model 
group) of entrepreneurial-intention implementation cues. Individually, entrepreneurial intention $(29.8 \%)$ and perceived behavioral control $(3.3 \%)$ of the experiential-model group, and entrepreneurial intention $(16.1 \%)$ of the traditional model group have explained the variance of entrepreneurialintention implementation cues of the participants of the study. The relationship between intention and its implementation-critical cue (EIIC) was found to be 0.76 .

Similar to these findings, Ajzen et al. (2009) reported that intention can account for substantial variance in actual behavior. Others reported that the correlation is as high as 0.96 (Smetana \& Adler, 1980), although in most cases, predictive accuracy is more modest. In a meta-analytical review of 185 studies conducted in the framework of the theory of planned behavior, Armitage and Conner (2001) and Sheeran (2002) reported that the average (27\% of the variation in behavior) was explained by behavioral intentions. On the other hand, meta-analytical works have shown that intentions account for between $20 \%$ and $30 \%$ of the variance in any behavior (Sheeran, 2002; Armitage \& Conner, 2001).

Therefore, the results obtained from the present study have concurred with those theoretical and empirical reports. Of course, intentional implementation cues could not be taken for granted for the occurrence of the actual behavior (in the context of this research venture creation).

\section{Conclusion}

In the light of the purposes of the study and the analysis presented above, specific conclusions were drawn from the findings of the present study. As the ANCOVA test result of the study confirmed, a significant mean difference in EI and its antecedents between the study groups taught entrepreneurship by the EELM and TETM has been obtained. The size effect of the experiential entrepreneurial learning method was found to be higher than the existing traditional entrepreneurial teaching method in EI, EIIC, EAT, and EPBC. However, there was no significant mean difference in ESNB between the two study groups. The relationships of entrepreneurial intention, its antecedents, and entrepreneurial intention were differently affected by the entrepreneurship course as regards the teaching-learning methods. The present research has indicated that teaching and learning in an entrepreneurial course in higher education for venture creation, which can be realized through enhancing entrepreneurial intentions and strong implementation of practical signals, demands psycho-educational learning theory-guided intervention strategies.

\section{References}

Ajzen, I. (1991). The theory of planned behavior. Organizational Behavior and Human Decision Processes, 50(2), 179-211. http://doi.org/10.1016/0749-5978(91)90020-t

Ajzen, I. (2001). Nature and operation of attitudes. Annual Review of Psychology, 52(1), 27-58. https://doi.org/10.1146/annurev.psych.52.1.27

Ajzen, I. Czasch, C., \& Flood, M. G. (2009). From intentions to behavior: Implementation intention, commitment, and conscientiousness. Journal ofAapplied Social Psychology, 39(6), 1356-1372. https://doi.org/10.1111/j.15591816.2009.00485.x 
Ajzen, I. (2014). The theory of planned behavior is alive and well, and not ready to retire: A commentary on Sniehotta, Presseau, and Araújo-Soares. Health Psychology Review, 9(2), 131-137. https:// doi.org/10.1080/17437199.2014.883474

Fishbein, M., \& Ajzen, I. (2009). Predicting and changing behavior: The reasoned action approach. Psychology Press. https://doi.org/10.4324/9780203838020

Armitage, C. J., \& Conner, M. (2001). Efficacy of the theory of planned behavior: A meta-analytic review. British Journal of Social Psychology, 40(4), 471-499. https://doi.org/10.1348/014466601164939

Autio, E., Keeley, R. H., Klofsten, M., Parker, C., \& Hay, M. (2001). Entrepreneurial intent among students in Scandinavia and in the USA. Enterprise and Innovation Management Studies 2(2), 145-160. https:/ / doi.org/10.1080/14632440110094632

Béchard, J.-P., \& Grégoire, D. (2005). Entrepreneurship education research revisited: The case of higher education. Academy of Management Learning $\mathcal{E}$ Education, 4(1), 22-43. https:// doi.org/10.5465/amle.2005.16132536

Biggs, J. (2012). What the student does: Teaching for enhanced learning. Higher Education Research $\mathcal{E}$ Development, 31(1), 39-55. https://doi.org/10.1080/07294360.2012.642839

Chen, C. C., Greene, P. G., \& Crick, A. (1998). Does entrepreneurial self-efficacy distinguish entrepreneurs from managers? Journal of Business Venturing, 13(4), 295-316. https://doi.org/10.1016/S0883-9026(97)00029-3

Chapman, J., Schetzsle, S., \& Wahlers, R. (2016). An innovative, experiential-learning project for sales management and professional selling students. Marketing Education Review, 26(1), 45-50. https://doi.org/10.1080/10528008.2015.1091674

Cook, T. D., \& Campbell, D. T. (1979). Quasi-Experimentation: Design and Analysis Issues for Field Settings. Houghton Mifflin.

Da Costa, T. G., \& Mares, P. (2016). Factors affecting students' entrepreneurial intentions of Polytechnic Institute of Setubal: A cognitive approach. $7(1)$. http://dx.doi.org/10.13059/racef.v7i1.175

Fayolle, A., Gailly, B., \& Lassas-Clerc, N. (2006). Assessing the impact of entrepreneurship education programmes: A new methodology. Journal of $\begin{array}{llll}\text { European Industrial Training, 301-720. } & \end{array}$ https://doi.org/10.1108/03090590610715022

Fayolle, A., \& Gailly, B. (2008). From craft to science: Teaching models and learning processes in entrepreneurship education. Journal of European Industrial Training, 32(7), 569-593. https:// doi.org/10.1108/03090590810899838

Fayolle, A., \& Gailly, B. (2015). The impact of entrepreneurship education on entrepreneurial attitudes and intention: Hysteresis and persistence. Journal of Small Business Management, 53(1), 75-93. https://doi.org/10.1111/jsbm.12065

Federal Democratic Republic of Ethiopia., Ministry of Education. (2009). Higher Education Proclamation No. 650/2009. Ethiopia: Berhanena Selam.

Federal Democratic Republic of Ethiopia., Ministry of Education (2018). Ethiopian education development roadmap (2018-30): An integrated executive summary: Draft for discussion. Addis Ababa: Ministry of Education, Education Strategy Center (ESC). https://planipolis.iiep.unesco.org/en/2018/ethiopian-education-

Feinstein, A. H., Mann, S., \& Corsun, D. L. (2002). Charting the experiential territory: Clarifying definitions and uses of computer simulation, games, and role-play. Journal of Management Development, 21(10), 732-744, https://doi.org/10.1108/02621710210448011 
Gerba, D. T. (2012). The context of entrepreneurship education in Ethiopian universities. Management Research Review, 35(3), 225-244. http://dx.doi.org/10.1108/01409171211210136

Gollwitzer, P. M., (1999). Implementation intentions: Strong effects of simple plans. American Psychologist, 54(7), 493-503. https://doi.org/10.1037/0003066x.54.7.493

Gollwitzer, P. M., \& Oettingen, G. (2015). From studying the determinants of action to analyzing its regulation: a commentary on Sniehotta, Presseau, and AraújoSoares. Health psychology review, 9(2), 146-150, https://doi.org/10.1080/17437199.2014.919511

Gollwitzer, P. M., \& Sheeran, P. (2006). Implementation intentions and goal achievement: A meta-analysis of effects and processes. Advances in Experimental Social Psychology, 38, 69-119. https://doi.org/10.1016/s00652601(06)38002-1

Hägg, G., \& Gabrielsson, J. (2019). A systematic literature review of the evolution of pedagogy in entrepreneurial education research. International Journal of Entrepreneurial Behavior \& Research, 26(5), 829-861.

Heinonen, J., \& Poikkijoki, S. A. (2006). An entrepreneurial-directed approach to entrepreneurship education: mission impossible? Journal of Management Development, 25(1), 80-94. https://doi.org/10.1108/02621710610637981

Higgins, D., \& Elliott, C. (2011). Learning to make sense: What works in entrepreneurial education? Journal of European Industrial Training, 35(4), 345367. https://doi.org/10.1108/03090591111128324

Huub, M., Gerba, D.T., \& Chekol, A. D. (2015). Entrepreneurship education in Ethiopian universities: Institutional assessment synthesis report. Working Papers 2015/01, Maastricht School of Management.

Järvi, T. (2015). Production of entrepreneurship in small business activities of students. Journal of Small Business and Enterprise Development, 22(1), 180-191. https://doi.org/10.1108/JSBED-02-2012-0023

Jones, B., \& Iredale, N. (2010). Enterprise education as pedagogy. Education + Training, 52(1), 7-19. https://doi.org/10.1108/00400911011017654

Karimi, S., Biemans, H. J., Lans, T., Chizari, M., \& Mulder, M. (2016). The impact of entrepreneurship education: A study of Iranian students' entrepreneurial intentions and opportunity identification. Journal of Small Business Management, 54(1), 187-209. https://doi.org/10.1111/jsbm.12137

Kolb, D. A. (1984). Experiential learning: Experience as the source of learning and development. Englewood Cliffs, NJ: Prentice-Hall.

Kolb, D. A. (2014). Experiential learning: Experience as the source of learning and development. FT Press.

Kolvereid, L. (1996). Prediction of Employment Status Choice Intentions. Entrepreneurship Theory and Practice, 21(1), 47-58. https:// doi.org/10.1177/104225879602100104

Kolvereid, L., \& Isaksen, E. (2006). New business start-up and subsequent entry into self-employment. Journal of Business Venturing, 21(6), 866-885, https://doi.org/10.1016/j.jbusvent.2005.06.008

Krueger, N. F. (2007). What lies beneath? The experiential essence of entrepreneurial thinking. Entrepreneurship Theory and Practice, 31(1), 123-138, https://doi.org/10.1111/j.1540-6520.2007.00166.x

Krueger, N. F., Reilly, M. D., \& Carsrud, A. L. (2000). Competing models of entrepreneurial intentions. Journal of Business Venturing, 15(5-6), 411-432. https:// doi.org/10.1016/S0883-9026(98)00033-0 
Lackéus, M., Lundqvist, M., \& Middleton, K. W. (2016). Bridging the traditionalprogressive education rift through entrepreneurship. International Journal of Entrepreneurial Behavior \& Research, 22(6), 777-803. https://doi.org/10.1108/ijebr-03-2016-0072

Lewis, L. H., \& Williams, C. J. (1994). Experiential learning: Past and present. New Directions for Adult and Continuing Education, 1994(62), 5-16, https://doi.org/10.1002/ace.36719946203

Laguía, A., Moriano, J. A., \& Gorgievski, M. J. (2019). A psychosocial study of selfperceived creativity and entrepreneurial intentions in a sample of university students. Thinking Skills and Creativity, 31, 44-57.

Leal-Rodríguez, A. L., \& Albort-Morant, G. (2019). Promoting innovative experiential learning practices to improve academic performance: Empirical evidence from a Spanish Business School. Journal of Innovation \& Knowledge, 4(2), 97-103. https://doi.org/10.1016/j.jik.2017.12.001

Liñán, F., \& Chen, Y. W. (2009). Development and cross-cultural application of a specific instrument to measure entrepreneurial intentions. Entrepreneurship Theory and Practice, 33(3), 593-617.

Malabana, M. J., \& Swanepoel, E. (2019). Graduate entrepreneurial intentions in the rural provinces of South Africa. Southern African Business Review, 19(1), 89-111. https://doi.org/10.25159/1998-8125/5835

Molla, T. (2018). Higher education in Ethiopia: Structural inequalities and policy responses. Springer. https://et1lib.org/book/3422375/810fca

Mueller, S. (2011). Increasing entrepreneurial intention: Effective entrepreneurship course characteristics. International Journal of Entrepreneurship and Small Business, 13(1), 55-74. https://doi.org/10.1504/IJESB.2011.040416

Mukesh, H. V., Pillai, K. R., \& Mamman, J. (2019). Action-embedded pedagogy in entrepreneurship education: An experimental inquiry. Studies in Higher Education, 1-15. https://doi.org/10.1080/03075079.2019.1599848

Mwasalwiba, E. S. (2010). Entrepreneurship education: A review of its objectives, teaching methods, and impact indicators. Education + Training, 52(1), 20-47. https://doi.org/10.1108/00400911011017663

Nabi, G., Liñán, F., Fayolle, A., Krueger, N., \& Walmsley, A. (2017). The impact of entrepreneurship education in higher education: A systematic review and research agenda. Academy of Management Learning \& Education, 16(2), 277-299. https:// doi.org/10.5465/amle.2015.0026

Oettingen, G., \& Gollwitzer, P., M. (2010). Strategies of setting and implementing goals: Mental contrasting and implementation intentions. Social Psychological Foundations of Clinical Psychology, 114-135. https:/ / psycnet.apa.org/record/2010-17975-007

Padilla-Angulo, L. (2017). Student associations and entrepreneurial intentions. Studies in Higher Education, 44(1), 45-58. https://doi.org/10.1080/03075079.2017.1336215

Panwar, S. K. (2020). The impact of entrepreneurship education on entrepreneurial intention: An empirical study of entrepreneurship education's four key characteristics (Doctoral dissertation). Brunel University London.

Park, E. L., \& Choi, B. K. (2014). Transformation of classroom spaces: Traditional versus active learning classroom in colleges. Higher Education, 68(5), 749-771. https://doi.org/10.1007/s10734-014-9742-0

Peterman, N., E., \& Kennedy, J. (2003). Enterprise education: Influencing students' perceptions of entrepreneurship. Entrepreneurship Theory and Practice, 28(2), 129-144. https:// doi.org/10.1046/j.1540-6520.2003.00035.x 
Reuel Johnmark, D., Munene, J. C., \& Balunywa, W. (2016). Robustness of personal initiative in moderating entrepreneurial intentions and actions of disabled students. Cogent Business \& Management, 3(1), 1169575. https://doi.org/10.1080/23311975.2016.1169575

Sánchez, J. C. (2013). The impact of an entrepreneurship education program on entrepreneurial competencies and intention. Journal of Small Business Management, 51(3), 447-465. https:// doi.org/10.1111/jsbm.12025

Schlaegel, C., \& Koenig, M. (2013). Determinants of entrepreneurial intent: A metaanalytic test and integration of competing models. Entrepreneurship Theory and Practice, 38(2), 291-332. https://doi.org/10.1111/etap.12087

Sheeran, P. (2002). Intention - behavior relations: A conceptual and empirical review. European Review of Social Psychology, 12(1), 1-36. https:// doi.org/10.1080/14792772143000003

Smetana, J. G., \& Adler, N. E. (1980). Fishbein's value x expectancy model. Personality and Social Psychology Bulletin, 6(1), 89-96. https://doi.org/10.1177/014616728061013

Souitaris, V., Zerbinati, S. \& Al-Laham, A. (2007). Do entrepreneurship programmes raise entrepreneurial intention of science and engineering students? The effect of learning, inspiration, and resources. Journal of Business Venturing, 22(4), 566591. https://doi.org/10.1016/j.jbusvent.2006.05.002

Tadesse, T., Manathunga, C. E., \& Gillies, R. M. (2018). Making sense of quality teaching and learning in higher education in Ethiopia: Unfolding existing realities for future promises. Journal of University Teaching and Learning Practice, 15(1), 23-43. https:// doi.org/10.53761/1.15.1.4

Tadesse, T., Gillies, R. M., \& Manathunga, C. (2020). The effects of informal cooperative learning pedagogy on teaching effectiveness, task orientation, and learning satisfaction in undergraduate classrooms in Ethiopia. Higher Education $\begin{array}{llll}\text { Research } \mathcal{E} \quad \text { Development } & \text { 40(3), }\end{array}$ https://doi.org/10.1080/07294360.2020.1765320

Tkachev, A., \& Kolvereid, L. (1999). Self-employment intentions among Russian students. Entrepreneurship \& Regional Development, 11(3), 269-280. https://doi.org/10.1080/089856299283209

Tung, L. C. (2011). The impact of entrepreneurship education on entrepreneurial intention of engineering students $[\mathrm{PhD}$ dissertation, City University of Hongkong]. http://lbms03.cityu.edu.hk/theses/c_ftt/phd-meemb40869337f.pdf

Usher, R., \& Solomon, N. (1999). Experiential learning and the shaping of subjectivity in the workplace. Studies in the Education of Adults, 31(2), 155-163. https://doi.org/10.1080/02660830.1999.11661409

Van Gelderen, M., Brand, M., Van Praag, M., Bodewes, W., Poutsma, E., \& Van Gils, A. (2008). Explaining entrepreneurial intentions by means of the theory of planned behavior. Career Development International, 13(6), 538-559. https://doi.org/10.1108/13620430810901688

Van Gelderen, M., Kautonen, T., \& Fink, M. (2015). From entrepreneurial intentions to actions: Self-control and action-related doubt, fear, and aversion. Journal of Business Venturing, 30(5), 655-673. https://doi.org/10.1016/j.jbusvent.2015.01.003

Zerihun, Z., Beishuizen, J. \& Van Os, W., (2012). Student learning experience as indicator of teaching quality. Educational Assessment, Evaluation and Accountability, 24(2), 99-111. https:// doi.org/10.1007/s11092-011-9140-4 